\title{
Effect of Monomer Structure on the Mechanical Properties of Light-cured Unfilled Resins
}

\author{
Minoru KAWAGUCHI, Tadao FUKUSHIMA and Takashi HORIBE \\ Department of Dental Materials and Devices, Fukuoka Dental College, $700 \mathrm{Ta}$, \\ Sawara-ku, Fukuoka 814-01, Japan
}

Received on July 27,1988

Accepted on October 7, 1988

The visible light-cured unfilled resins using the nine types of aromatic dimethacrylates were investigated to determine the effects of the monomer structure on selected properties. Analysis of the data indicated that the mechanical properties of these unfilled resins were much dependent upon the monomer structure. There was also a correlation between the water sorption value of the unfilled resins and the reduction in their mechanical properties under wet conditions. The results of this investigation indicated that the fluoro groups-containing dimethacrylate resin would be the effective resin system for visible light-cured dental restorative materials.

Key words: Unfilled resin, Photopolymerization, Mechanical properties

\section{INTRODUCTION}

Since Bis-GMA monomer was introduced as a dental resin component by Bowen ${ }^{1)}$, it has continued to be the most extensively used in dental resins such as composite restorative resins and fissure sealants $s^{2-4)}$.

Bis-GMA has a rigid bisphenol A backbone in its chemical structure. The bulky nature of the bisphenol A group leads to a rigid polymer with lower polymerization shrinkage. However, the Bis-GMA-based materials showed a relatively higher water sorption due to the two hydroxy groups in the Bis-GMA molecule ${ }^{5)}$. Absorbed water in Bis-GMA-based composite resins can release internal stress, promote filler-resin debonding, and reduce the mechanical properties of the composite materials. The structure of the dimethacrylates containing the bisphenol backbone, as well as their concentration in resin systems, affects the mechanical properties and water sorption of the cured resin.

The objective of this study was to investigate the effects of the monomer structure of nine types of aromatic dimethacrylates on the mechanical properties and the water sorption in unfilled resin systems.

\section{MATERIALS AND METHODS}

\section{Preparation of aromatic dimethacrylates}

The chemical formulas of the nine types of aromatic dimethacrylates used in this study and their synthetic schemes are given in Fig. 1.

Bis-GMA-F and Bis-GMA-C were prepared according to the method of Brzozowski and Nowicki ${ }^{6)}$ (scheme 1) and purified using column chromatography. Bisphenol $\mathrm{C}$ was obtained 


\section{scheme 1}
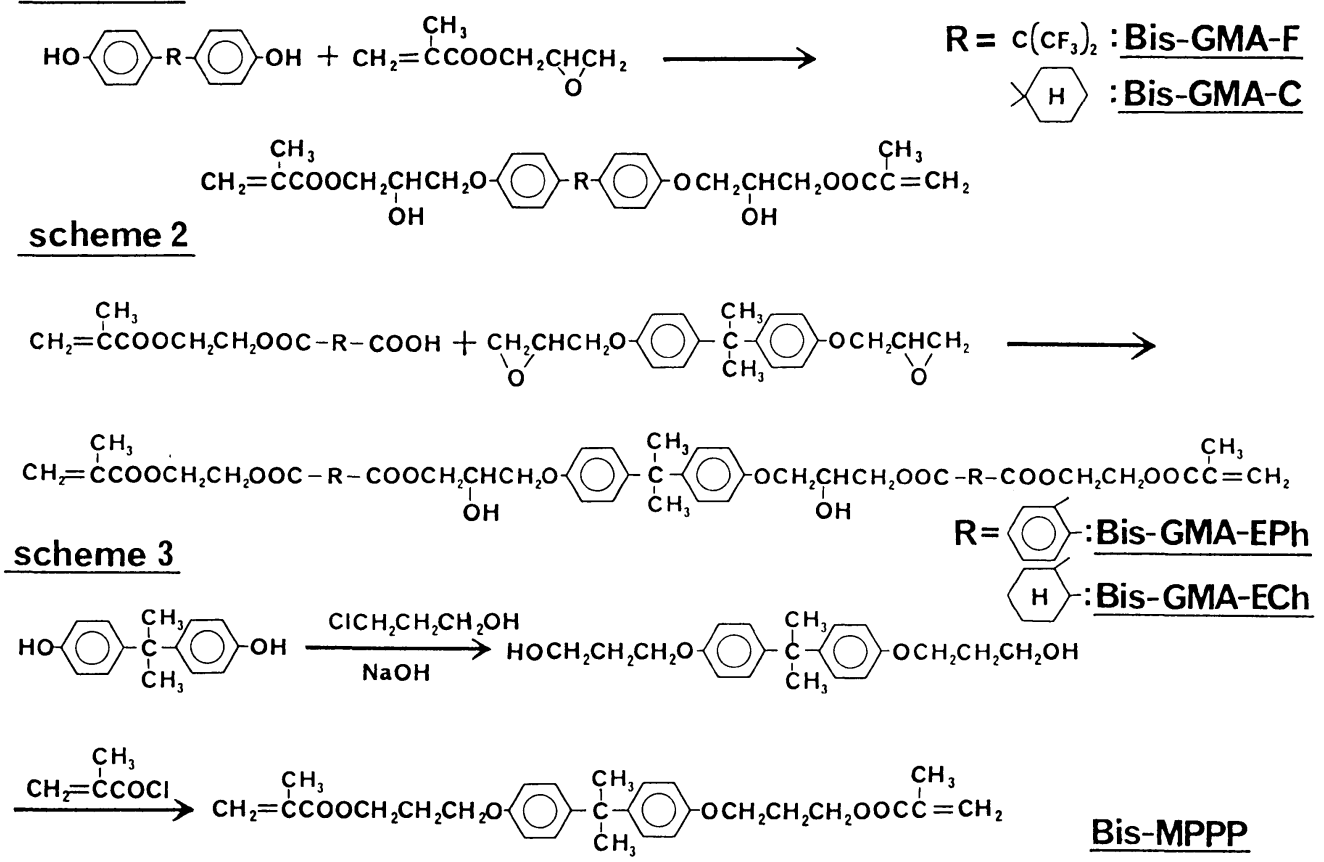

Bis-MPPP

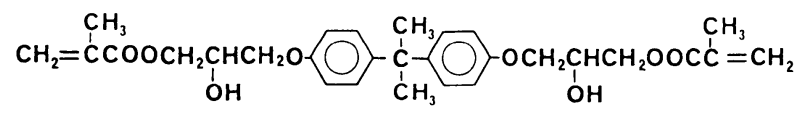

Bis-GMA

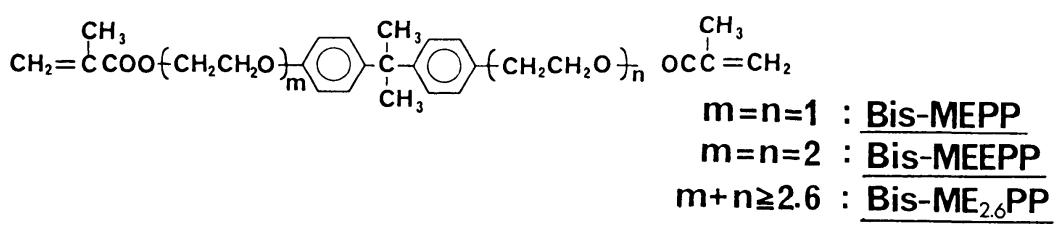

Fig. 1 Synthetic schemes and structural formulas of aromatic dimethacrylates.

as described in the literature ${ }^{7)}$. Bis-GMA-EPh and Bis-GMA-ECh were prepared according to scheme 2. The preparation of methacryloxyethyl hydrogen phthalate and methacryloxyethyl hydrogen hexahydrophthalate was carried out by a similar method of Fukushima et $a l .^{8}$. Bis-MPPP was prepared according to scheme 3 , and purified by using column chromatography (silicagel ; Lobar type $C^{*}$, eluent ; benzene/ethyl acetate $90 / 10 \mathrm{v} / \mathrm{v}$ ). The preparation of Bis-MEPP, Bis-MEEPP, and Bis-GMA was conducted as previously described $^{9-10}$. Commercially available Bis- $\mathrm{ME}_{2.6} \mathrm{PP}^{* *}$ was used without further purification.

\section{Preparation of test specimens}

Each aromatic dimethacrylate was diluted with triEDMA** in a molar ratio of $1 / 1$.

*LiChroprep Si 60, Merck, Darmstadt, Germany

**Shin-Nakamura Chemical Co., LTD., Wakayama, Japan 
Photosensitizer $(0.5 \mathrm{wt} \%$ of camphoroquinone $* * *$ and $1.0 \mathrm{wt} \%$ of $\mathrm{N}, \mathrm{N}$-dimethylaminoethyl methacrylate ${ }^{\#}$ ) was added to the monomer to prepare nine types of visible light-cured unfilled resin systems.

They were poured into an aluminium mold with the ends covered by glass plates $(0.7 \mathrm{~mm}$ thick) and irradiated twice through both glass plates with a light source ${ }^{\# \#}$ to make specimens of flexural strength which conform to elastic modulus measurements. After the cured resins were removed from the mold, the bar specimens $(2 \times 2 \times 30 \mathrm{~mm})$ for each resin system were made by cutting with a low-speed diamond saw $\# \#$ and subsequently finished with 600 -grit wet $\mathrm{SiC}$ paper.

The unfilled resins were poured into a glass tube $\left(4 \mathrm{~mm}^{\phi} \times 40 \mathrm{~mm}\right)$ and irradiated in four different directions for each $90 \mathrm{~s}$ to ensure optimal conversion. The cured resins were cut with a low-speed diamond saw to make specimens of the compressive proportional limit and diametral tensile strength $\left(4 \mathrm{~mm}^{\phi} \times 6 \mathrm{~mm}\right.$ for compressive proportional limit measurement, and $4 \mathrm{~mm}^{\phi} \times 4 \mathrm{~mm}$ for diametral tensile strength measurements).

For water sorption measurements, three disc specimens, $20 \mathrm{~mm}$ in diameter and $1 \mathrm{~mm}$ thick, were made from the resin which were cured in glass plate-covered aluminium molds by $120 \mathrm{~s}$ illuminations through both glass plates.

Each specimen was divided into two groups. One group was kept at $37^{\circ} \mathrm{C}$ in a dessicator for 30 days (dry conditions) and the other was immersed in distilled water at $37^{\circ} \mathrm{C}$ for 30 days (wet conditions).

\section{Measurement of mechanical properties}

The flexural strength and elastic modulus were measured on the bar specimens $(n=10)$ by a three-point bending test with a universal testing machine ${ }^{\# \# \#}$ at a cross-head speed of 1 $\mathrm{mm} / \mathrm{min}$. The length between the supports was $20 \mathrm{~mm}$. The elastic modulus was determined from the flexural stress-strain curves. The compression test $(n=7)$ was carried out with a constant cross-head speed of $1 \mathrm{~mm} / \mathrm{min}$. The proportional limits on the compression test were determined because these unfilled resins were not completely brittle. A diametral tensile strength test $(n=7)$ was carried out at a cross-head speed of $10 \mathrm{~mm} / \mathrm{min}$. Since the test specimen showed a large plastic deformation when tested, the tensile strength determined from the proportional limit was calculated as the diametral tensile strength.

\section{Water sorption}

Three disc specimens were conditioned to a constant weight in a dessicator and subsequently immersed in distilled water at $37^{\circ} \mathrm{C}$. The specimens were re-conditioned to a constant weight in a dessicator under vacuum two months after immersion in water. The water sorption for each resin system was determined from the differences in weight between the specimen immersed for two months and the re-conditioned specimen. The water sorption results in this study are expressed in $\mu \mathrm{g} / \mathrm{mm}^{3}$.

\section{Data analysis}

\footnotetext{
***Aldrich Chemical Co., WIS, USA

\#Nacalai Tesque, Kyoto, Japan

\#\#)ntacolor XS, Kulzer and Co., Wehrhelm, Germany

\#\#Isomet, Buhler, Evanston, IL, USA

\#\#\#Shimadzu IS-5000, Kyoto, Japan
} 
The data were analyzed with Scheffe's test for multiple comparisons between the means at a significant level of 0.05 .

\section{RESULTS}

The IR spectra assignments and NMR chemical shifts, and elemental analyses of newly synthesized aromatic dimethacrylates (Bis-GMA-F, Bis-GMA-C, Bis-GMA-EPh, Bis-GMA -ECh, and Bis-MPPP) are listed in Tables 1 and 2, respectively. The IR and NMR spectra data were consistent with assigned structure of each monomer. The elemental analyses were also reasonably consistent with the chemical formula assigned to them.

Mechanical properties of the unfilled dimethacrylate resins are summarized in Table 3. The results of the Scheffe's test for multiple comparisons of the mechanical properties are shown in Table 4.

The unfilled resins based on dimethacrylates containing hydroxy groups (Bis-GMA, Bis -GMA-F, Bis-GMA-C, Bis-GMA-EPh, and Bis-GMA-ECh) showed a relatively large decrease in flexural strength under wet conditions. In contrast, the resins based on dimethacrylates without the hydroxy group showed only a slight decrease in flexural strength under

Table 1 IR assignments and NMR chemical shifts of aromatic dimethacrylates

\begin{tabular}{|c|c|c|}
\hline & IR absorption bands $\left(\mathrm{cm}^{-1}\right)$ & NMR chemical shifts (ppm) \\
\hline Bis-GMA-F & $\begin{array}{l}3600-3200(\mathrm{OH}), 2950\left(\mathrm{CH}_{2}\right) \\
1720(\mathrm{C}=\mathrm{O}), 1640(\mathrm{C}=\mathrm{C}) \\
1040(\mathrm{C}-\mathrm{O}), 1200\left(\mathrm{CF}_{3}\right) \\
940(\mathrm{CH})\end{array}$ & $\begin{array}{l}1.92\left(6 \mathrm{H},-\mathrm{CH}_{3}\right), 3.10(2 \mathrm{H},-\mathrm{OH}), 3.90-4.45(8 \mathrm{H}, \\
\left.-\mathrm{CH}_{2}-\right), 5.58 \text { and } 6.10\left(4 \mathrm{H}, \mathrm{CH}_{2}=\right), 6.75-7.40 \\
(8 \mathrm{H} \text {, aromatic })\end{array}$ \\
\hline Bis-GMA-C & $\begin{array}{l}3640-3190(\mathrm{OH}), 2960\left(\mathrm{CH}_{2}\right) \\
1720(\mathrm{C}=\mathrm{O}), 1640(\mathrm{C}=\mathrm{C}) \\
1450\left(\mathrm{CH}_{2}\right), 1050(\mathrm{C}-\mathrm{O})\end{array}$ & $\begin{array}{l}1.93\left(6 \mathrm{H},-\mathrm{CH}_{3}\right), 1.50-2.22(10 \mathrm{H}, \text { cyclohexane }), \\
2.87(2 \mathrm{H},-\mathrm{OH}), 3.95-4.35\left(10 \mathrm{H},-\mathrm{CH}_{2} \mathrm{CHCH}_{2}\right), 5.56 \\
\text { and } 6.12\left(4 \mathrm{H}, \mathrm{CH}_{2}=\right), 6.68-7.26(8 \mathrm{H}, \text { aromatic })\end{array}$ \\
\hline Bis-GMA-EPh & $\begin{array}{l}3630-3250(\mathrm{OH}), 2960\left(\mathrm{CH}_{2}\right) \\
1730(\mathrm{C}=\mathrm{O}), 1640(\mathrm{C}=\mathrm{C}) \\
1045\left(\mathrm{CH}_{2}\right), 940(\mathrm{CH})\end{array}$ & $\begin{array}{l}1.57(6 \mathrm{H},-\mathrm{CH}), 1.96\left(6 \mathrm{H},-\mathrm{CH}_{3}\right), 3.15(2 \mathrm{H},-\mathrm{OH}) \text {, } \\
3.98-4.15\left(10 \mathrm{H},-\mathrm{CH}_{2} \mathrm{CHCH}_{2}-\right), 4.45\left(8 \mathrm{H},-\mathrm{CH}_{2}-\right) \text {, } \\
5.52 \text { and } 6.10\left(4 \mathrm{H}, \mathrm{CH}_{2}=\right), 6.70-7.23 \text { and } 7.40^{-} \\
7.80(16 \mathrm{H} \text {, aromatic })\end{array}$ \\
\hline Bis-GMA-ECh & $\begin{array}{l}3650-3200(\mathrm{OH}), 2940\left(\mathrm{CH}_{2}\right) \\
1720(\mathrm{C}=\mathrm{O}), 1640(\mathrm{C}=\mathrm{C}) \\
1450\left(\mathrm{CH}_{2}\right), 1040(\mathrm{C}-\mathrm{O})\end{array}$ & $\begin{array}{l}1.60\left(6 \mathrm{H},-\mathrm{CH}_{3}\right), 1.97\left(6 \mathrm{H},-\mathrm{CH}_{3}\right), 1.40-1.98(16 \mathrm{H}, \\
\text { cyclohexane }), 2.80-3.05(6 \mathrm{H},-\mathrm{CH}-), 3.12(2 \mathrm{H},-\mathrm{OH}), \\
3.95-4.20\left(10 \mathrm{H},-\mathrm{CH}_{2} \mathrm{CHCH}_{2}\right), 4.39\left(8 \mathrm{H},-\mathrm{CH}_{2}-\right), \\
5.60 \text { and } 6.12\left(4 \mathrm{H}, \mathrm{CH}_{2}=\right), 6.70-7.35(8 \mathrm{H}, \text { aromatic })\end{array}$ \\
\hline Bis-MPPP & $\begin{array}{l}2960\left(\mathrm{CH}_{2}\right), 1720(\mathrm{C}=\mathrm{O}) \\
1640(\mathrm{C}=\mathrm{C}), 1045(\mathrm{C}-\mathrm{O}) \\
940(\mathrm{CH})\end{array}$ & $\begin{array}{l}1.62\left(6 \mathrm{H},-\mathrm{CH}_{3}\right), 1.95\left(6 \mathrm{H},-\mathrm{CH}_{3}\right), 3.90-4.35(12 \mathrm{H}, \\
\left.-\mathrm{CH}_{2}-\right), 5.52 \text { and } 6.09\left(4 \mathrm{H}, \mathrm{CH}_{2}=\right), 6.70-7.40(8 \mathrm{H} \text {, } \\
\text { aromatic) }\end{array}$ \\
\hline
\end{tabular}

Table 2 Elemental analyses of aromatic dimethacrylates

\begin{tabular}{lcl}
\hline & Calculated (\%) & Found (\%) \\
\hline Bis-GMA-F & $\mathrm{C}: 56.13$ & $\mathrm{C}: 55.99$ \\
Bis-GMA-C & $\mathrm{H}: 4.87$ & $\mathrm{H}: 4.90$ \\
& $\mathrm{C}: 69.55$ & $\mathrm{C}: 69.38$ \\
Bis-GMA-EPh & $\mathrm{H}: 7.30$ & $\mathrm{H}: 7.40$ \\
Bis-GMA-ECh & $\mathrm{C}: 65.62$ & $\mathrm{C}: 65.49$ \\
Bis-MPPP & $\mathrm{H}: 5.84$ & $\mathrm{H}: 5.91$ \\
& $\mathrm{C}: 64.74$ & $\mathrm{C}: 64.55$ \\
& $\mathrm{H}: 7.10$ & $\mathrm{H}: 7.29$ \\
& $\mathrm{C}: 72.48$ & $\mathrm{C}: 72.20$ \\
& $\mathrm{H}: 7.55$ & $\mathrm{H}: 7.48$ \\
\hline
\end{tabular}


Table 3 Mechanical properties of unfilled dimethacrylate resins

\begin{tabular}{|c|c|c|c|c|c|c|}
\hline $\begin{array}{l}\text { Monomer } \\
\text { composition } \\
(\text { mol\%) }\end{array}$ & & $\begin{array}{l}\text { Flexural } \\
\text { strength } \\
(\mathrm{MPa})\end{array}$ & $\begin{array}{l}\text { Elastic } \\
\text { modulus } \\
(\mathrm{GPa})\end{array}$ & $\begin{array}{l}\text { Compressive } \\
\text { proportional } \\
\text { limit } \\
(\mathrm{MPa})\end{array}$ & $\begin{array}{l}\text { Diametral } \\
\text { tensile } \\
\text { strength } \\
\text { (MPa) }\end{array}$ & $\begin{array}{l}\text { Amount of } \\
\text { water } \\
\text { sorption } \\
\left(\mu \mathrm{g} / \mathrm{mm}^{3}\right)\end{array}$ \\
\hline $\begin{array}{l}\text { Bis-GMA } \\
\quad: \text { triEDMA }=50: 50\end{array}$ & $\begin{array}{l}\text { dry } \\
\text { wet }\end{array}$ & $\begin{aligned} 149.1 & (7.3) \\
99.7 & (4.6)\end{aligned}$ & $\begin{array}{ll}3.53 & (0.05) \\
2.15 & (0.06)\end{array}$ & $\begin{array}{r}116.3(5.7) \\
76.1(2.2)\end{array}$ & $\begin{array}{l}430.2(0.7) \\
324.0(0.8)\end{array}$ & $58.9(0.03)$ \\
\hline $\begin{array}{l}\text { Bis-GMA-F } \\
\quad: \text { triEDMA }=50: 50\end{array}$ & $\begin{array}{l}\text { dry } \\
\text { wet }\end{array}$ & $\begin{array}{l}156.7(6.6) \\
119.6(6.6)\end{array}$ & $\begin{array}{ll}3.74 & (0.09) \\
2.87 & (0.07)\end{array}$ & $\begin{array}{r}118.9(2.6) \\
99.6(1.6)\end{array}$ & $\begin{array}{l}438.0(10.0) \\
345.1(13.3)\end{array}$ & $55.4(0.04)$ \\
\hline $\begin{array}{l}\text { Bis-GMA-C } \\
\quad: \text { triEDMA }=50: 50\end{array}$ & $\begin{array}{l}\text { dry } \\
\text { wet }\end{array}$ & $\begin{array}{rr}101.1 & (2.6) \\
80.3 & (2.4)\end{array}$ & $\begin{array}{ll}2.51 & (0.05) \\
1.22 & (0.04)\end{array}$ & $\begin{array}{ll}74.6 & (2.6) \\
56.1 & (1.6)\end{array}$ & $\begin{array}{l}305.1(9.4) \\
246.5(6.0)\end{array}$ & $62.3(0.02)$ \\
\hline $\begin{array}{l}\text { Bis-GMA-EPh } \\
\quad ; \text { triEDMA }=50 ; 50\end{array}$ & $\begin{array}{l}\text { dry } \\
\text { wet }\end{array}$ & $\begin{aligned} 101.7 & (3.2) \\
61.4 & (1.3)\end{aligned}$ & $\begin{array}{ll}2.64 & (0.10) \\
1.50 & (0.05)\end{array}$ & $\begin{array}{r}101.9(1.3) \\
66.2(1.9)\end{array}$ & $\begin{array}{l}385.2(4.6) \\
243.8(4.8)\end{array}$ & $35.4(0.10)$ \\
\hline $\begin{array}{l}\text { Bis-GMA-ECh } \\
\quad ; \text { triEDMA }=50: 50\end{array}$ & $\begin{array}{l}\text { dry } \\
\text { wet }\end{array}$ & $\begin{array}{rr}113.4 & (2.7) \\
70.2 & (5.1)\end{array}$ & $\begin{array}{l}2.85(0.11) \\
1.83(0.08)\end{array}$ & $\begin{array}{l}99.0(2.0) \\
67.2(8.4)\end{array}$ & $\begin{array}{l}367.2(2.9) \\
260.1(5.6)\end{array}$ & $40.2(0.04)$ \\
\hline $\begin{array}{l}\text { Bis-MEPP } \\
\quad: \text { triEDMA }=50: 50\end{array}$ & $\begin{array}{l}\text { dry } \\
\text { wet }\end{array}$ & $\begin{array}{l}170.3(7.3) \\
123.8(6.1)\end{array}$ & $\begin{array}{l}2.96(0.06) \\
2.89(0.07)\end{array}$ & $\begin{array}{ll}91.1 & (1.3) \\
85.1 & (1.9)\end{array}$ & $\begin{array}{l}383.3(8.8) \\
329.6(9.4)\end{array}$ & $20.5(0.04)$ \\
\hline $\begin{array}{l}\text { Bis-MEEPP } \\
\quad: \text { triEDMA }=50: 50\end{array}$ & $\begin{array}{l}\text { dry } \\
\text { wet }\end{array}$ & $\begin{array}{ll}96.6 & (2.4) \\
93.8 & (1.5)\end{array}$ & $\begin{array}{ll}2.19 & (0.06) \\
1.31 & (0.02)\end{array}$ & $\begin{array}{l}68.0(1.6) \\
59.3(2.4)\end{array}$ & $\begin{array}{l}269.7(7.3) \\
247.6(2.8)\end{array}$ & $22.5(0.05)$ \\
\hline $\begin{array}{l}\text { Bis-MPPP } \\
\quad: \text { triEDMA }=50: 50\end{array}$ & $\begin{array}{l}\text { dry } \\
\text { wet }\end{array}$ & $\begin{array}{ll}113.1 & (4.3) \\
107.6 & (3.4)\end{array}$ & $\begin{array}{ll}2.48 & (0.04) \\
2.33 & (0.04)\end{array}$ & $\begin{array}{ll}84.5 & (2.2) \\
78.7 & (2.7)\end{array}$ & $\begin{array}{l}337.7(9.6) \\
324.0(8.3)\end{array}$ & $16.8(0.10)$ \\
\hline $\begin{array}{l}\text { Bis }-\mathrm{ME}_{2.6} \mathrm{PP} \\
\quad: \text { triEDMA }=50: 50\end{array}$ & $\begin{array}{l}\text { dry } \\
\text { wet }\end{array}$ & $\begin{array}{l}120.7(4.6) \\
115.7(2.4)\end{array}$ & $\begin{array}{ll}2.72 & (0.05) \\
2.57 & (0.08)\end{array}$ & $\begin{array}{l}82.4(2.3) \\
79.7(1.0)\end{array}$ & $\begin{array}{l}357.7(7.2) \\
326.6(4.0)\end{array}$ & $18.2(0.02)$ \\
\hline
\end{tabular}

(SD in parentheses)

Table 4 Results of comparison test for the mechanical properties

\begin{tabular}{|c|c|c|c|c|}
\hline & Flexural strength & Elastic modulus & $\begin{array}{l}\text { Compressive } \\
\text { proportional limit }\end{array}$ & $\begin{array}{c}\text { Diametral } \\
\text { tensile strength }\end{array}$ \\
\hline Dry & $\begin{array}{l}\text { Bis-MEPP } \\
\text { Bis-GMA-F } \\
\text { Bis-GMA } \\
\text { Bis-ME } \\
\text { Bis-GMA-EP } \\
\text { Bis-MPPP } \\
\text { Bis-GMA-EPh } \\
\text { Bis-GMA-C } \\
\text { Bis-MEEPP }\end{array}$ & $\begin{array}{l}\text { Bis-GMA-F } \\
\text { Bis-GMA } \\
\text { Bis-MEPP } \\
\text { Bis-GMA-ECh } \\
\text { Bis-ME } \\
\text { Bis-GPP } \\
\text { Bis-GMA-EPh } \\
\text { Bis-MPPP } \\
\text { Bis-MEEPP }\end{array}$ & $\begin{array}{l}\text { Bis-GMA-F } \\
\text { Bis-GMA } \\
\text { Bis-GMA-EPh } \\
\text { Bis-GMA-ECh } \\
\text { Bis-MEPP } \\
\text { Bis-MPPP } \\
\text { Bis-ME }_{2.6} \text { PP } \\
\text { Bis-GMA-C } \\
\text { Bis-MEEPP }\end{array}$ & $\begin{array}{l}\text { Bis-GMA-F } \\
\text { Bis-GMA } \\
\text { Bis-GMA-EPh } \\
\text { Bis-MEPP } \\
\text { Bis-GMA-ECh } \text { Bis-ME }_{2.6} \text { PP } \\
\text { Bis-MPPP }_{\text {Bis-GMA-C }} \\
\text { Bis-MEEPP }\end{array}$ \\
\hline Wet & $\begin{array}{l}\text { Bis-MEPP } \\
\text { Bis-GMA-F } \\
\text { Bis-ME }{ }_{2.6} P P \\
\text { Bis-MPPP } \\
\text { Bis-GMA } \\
\text { Bis-MEEPP } \\
\text { Bis-GMA-C } \\
\text { Bis-GMA-ECh } \\
\text { Bis-GMA-EPh }\end{array}$ & $\begin{array}{l}\text { Bis-MEPP } \\
\text { Bis-GMA-F } \\
\text { Bis-ME }_{2.6} P P \\
\text { Bis-MPPP } \\
\text { Bis-GMA } \\
\text { Bis-GMA-ECh } \\
\text { Bis-GMA-EPh } \\
\text { Bis-MEEPP } \\
\text { Bis-GMA-C }\end{array}$ & $\begin{array}{l}\text { Bis-GMA-F } \\
\text { Bis-MEPP } \\
\text { Bis-ME }_{2.6} \text { PP } \\
\text { Bis-MPP } \\
\text { Bis-GMA } \\
\text { Bis-GMA-ECh } \\
\text { Bis-GMA-EPh } \\
\text { Bis-MEEPP } \\
\text { Bis-GMA-C }\end{array}$ & $\begin{array}{l}\text { Bis-GMA-F } \\
\text { Bis-MEPP } \\
\text { Bis-ME }{ }_{2.6} P P \\
\text { Bis-MPP } \\
\text { Bis-GMA } \\
\text { Bis-GMA-ECh } \\
\text { Bis-MEEPP } \\
\text { Bis-GMA-C } \\
\text { Bis-GMA-EPh }\end{array}$ \\
\hline
\end{tabular}

Resins connected by bars were not significantly different. 
wet conditions, except for the Bis-MEPP resin. Although the flexural strength of the Bis -GMA, Bis-GMA-F, and Bis-MEPP resins were higher than that of the other resins under dry conditions, the Bis-GMA-F and Bis-MEPP resins showed a significantly higher flexural strength than the Bis-GMA resin under wet conditions.

The Bis-GMA and Bis-GMA-F resins have a higher flexural strength and elastic modulus. The elastic modulus of the Bis-GMA-C, Bis-GMA-EPh, and Bis-GMA-ECh resins was significantly lower than that of the Bis-GMA and Bis-GMA-F resins under both dry and wet conditions. The Bis-MEPP, Bis-MPPP, and Bis-ME $\mathrm{E}_{2.6} \mathrm{PP}$ resins showed a slight decrease in elastic modulus under wet conditions, while the Bis-MEEPP resin showed a significant decrease.

There was significant difference $(\mathrm{p}<0.05)$ between the compressive propotional limit of the hydroxy group-containing dimethacrylate resins and the other resins, except for the Bis -GMA-C resin, under dry conditions. The Bis-GMA-C resin showed a significantly lower compressive proportional limit than the other hydroxy group-containing dimethacrylate resins under both dry and wet conditions. The decrease in compressive proportional limit of the Bis-MEPP, Bis-MEEPP, Bis-MPPP, and Bis- $\mathrm{ME}_{2.6} \mathrm{PP}$ resins in water were lower than that of the hydroxy group-containing dimethacrylate resins.

The diametral tensile strength of the unfilled resins were slightly decreased under wet conditions. The decrease in diametral tensile strength of the hydroxy group-containing dimethacrylate resins was higher than that of the other resins. These results correlate with the above-mentioned results in flexural and compression testing.

The water sorption value of the hydroxy group-containing dimethacrylate resins was higher than that of the other resins. The resins based on hydrophobic dimethacrylates (Bis -GMA-F, Bis-GMA-EPh, and Bis-GMA-ECh) showed relatively lower water sorption than the Bis-GMA resin.

\section{DISCUSSION}

Analysis of the results obtained in this investigation indicated that the mechanical properties were clearly dependent on the structural nature of the dimethacrylate. The seven types of dimethacrylates contain a bisphenol A backbone. Previous report indicates that a dimethacrylate containing a bisphenol A backbone is a rigid and brittle polymer ${ }^{11}$. As would be expected from the report, the Bis-GMA and Bis-MEPP resins were highly brittle nature under dry conditions. However, the mechanical properties of this Bis-GMA resin significantly decreased under wet conditions as compared with the Bis-MEPP resin. It was also found that the mechanical properties of the other hydroxy group-containing resins decreased under wet conditions.

Bis-GMA-EPh and Bis-GMA-ECh containing an additional two aromatic (phthaloyl groups) or cyclohexane (hexahydro phthaloyl groups) rings, respectively, are relatively higher molecular weight dimethacrylates $(\mathrm{Mw}=869.9$ and 909.0, respectively) than Bis-GMA. As expected, these dimethacrylate resins showed a more hydrophobic nature than the Bis-GMA resin. However, the mechanical properties were lower than Bis-GMA due to their higher segmental mobility. If these types of dimethacrylates are used in resin components, they are 
capable of giving strength, impact resistance, and a lower polymerization shrinkage to the cured resins.

On the other hand, the mechanical properties of the dimethacrylates without hydroxy groups (Bis-MEPP, Bis-MEEPP, Bis-MPPP, and Bis-ME ${ }_{2.6} \mathrm{PP}$ greatly depended upon the segmental mobility of their aliphatic side chains. The Bis-MEPP resin showed a highly brittle nature, while the resin based on Bis-MEEPP, which contained longer side chains, was flexible. Since the oligomeric Bis- $\mathrm{ME}_{2.6} \mathrm{PP}$ which has been used as resin system for some dental composite resins, is a mixture of a dimethacrylates with various lengths of side chains, the mechanical properties of the Bis- $\mathrm{ME}_{2.6} \mathrm{PP}$ resin could not be compared with those of the other dimethacrylate resins.

The Bis-GMA-C has a cyclohexane ring in their backbone. This cyclohexane ring could result in increasing the steric hindrance on the network formation, which results in increasing the residual unsaturation in cured materials. The limited mechanical properties of the Bis -GMA-C resin would be caused by these polymerization defect.

With respect to the Bis-GMA-F monomer, the fluoro group-containing dimethacrylate has some advantages for use as a dental resin system. Hirabayashi and Hirasawa ${ }^{12)}$ reported that the fluorine-containing dimethacrylates were effective in decreasing the refractive index of the monomers. Furthermore, several researchers indicated that fluoro group-containing monomers increased the hydrophobility of their polymers ${ }^{13,14}$. In fact, the Bis-GMA-F resin in this investigation showed higher mechanical properties than the Bis-GMA resin under wet conditions. These findings suggested that the Bis-GMA-F resin system would be effective for the base monomer system in visible light-cured dental composite resins.

\section{CONCLUSIONS}

Nine types of photopolymerizable unfilled resins were prepared, and the effects of monomer structure on the mechanical properties of the cured materials were investigated. The results of this investigation revealed that the mechanical properties of these unfilled resins were highly dependent upon the monomer structure. The hydroxy groups-containing dimethacrylate resins showed a relatively higher reduction in mechanical properties under wet conditions as compared with those under dry conditions due to the higher water sorption for these resins. On the other hand, the mechanical properties of the resins based on dimethacrylate without the hydroxy groups were related to the segmental mobility of their side chains. The results of this study also indicated that the fluoro groups-containing dimethacrylate resin would be an effective resin system for visible light-cured dental restorative materials.

\section{REFERENCES}

1) Bowen, R. L. : Dental filling material comprising vinyl silane treated fused silica and a binder consisting of the reaction product of bis phenol and glycidyl acrylate, US patent 3,066,112, 1962 .

2) Ruyter, I. E. and Sjфvik, I. J. : Composition of dental resin and composite materials, Acta Odontol Scand 39 (3) : 133-146, 1981. 
3) Wright, J. T. and Retief, D. H. : Laboratory evaluation of eight pit and fissure sealants, Pediatric Dent 6 (1) : 36-40, 1984.

4) Ruyter, I. E. and Øysaed, H. : Composites for use in posterior teeth : Composition and conversion, $J$ Biomed Mater Res 21 (1): 11-23, 1987.

5) Kalachandra, S. and Turner, D. T.: Water sorption of polymethacrylate networks: Bis-GMA/ TEGDM copolymers, J Biomed Mater Res 21 (3) : 329-338, 1987.

6) Brzozowski, Z. K. and Nowicki, A.: Unsaturated resins obtained from bisphenols and glycidyl esters of acrylic acids, J Polym Sci, Polym Chem Ed 13 (6) : 1479-1487, 1975.

7) Parsania, P. H., Shah, P. P., Patel, K. C. and Patel, R. D. : Synthesis and characterization of the poly-(2 -methoxycyanurate) of 1, 1'-bis-(4-hydroxyphenyl)-cyclohexane, J Macromol Sci-Chem A22 (11): 1495-1508, 1985.

8) Fukushima, T., Kawaguchi, M., Inoue, Y., Miyazaki, K. and Horibe, T. : A. : Application of functional monomers for dental use (part-9) Syntheses of succinoxy methacrylates and their adhesion to polished and etched tooth surfaces, Dent Mater J 4 (1): 33-39, 1985.

9) Kawaguchi, M., Fukushima, T., Miyazaki, M., Horibe, T., Habu, T., Sawamura, N. and Nagaoka, K. : Synthesis and physical properties of polyfunctional methacrylates (part-3) Physical properties of 2,2 -bis (4-methacryloxy ethoxy phenyl) sulfone copolymers and 2, 2-bis (4-methacryloxy ethoxy phenyl) propane copolymers with methyl methacrylate, J Fukuoka D C 10 (3): 453-460, 1983.

10) Kawaguchi, M., Fukushima, T. and Horibe, T.: Mechanical and physical properties of 2, 2'-bis (4 -methacryloxy polyethoxyphenyl) propane polymers, Dent Mater J 6 (2) : 148-155, 1987.

11) Kawaguchi, M., Fukushima, T., Miyazaki, K., Horibe, T., Habu, T. and Sawamura, N.: Synthesis and physical properties of polyfunctional methacrylates (part 4). Synthesis and physical properties of aromatic dimethacrylate copolymers, Dent Mater J 3 (2) : 272-279, 1984.

12) Hirabayashi, S. and Hirasawa, T. : Synthesis of monomers for dental light-cured composite resins and physical properties of these bulk polymers, J J Dent Mater 7 (2): 197-204, 1988. (in Japanese)

13) Griffith, J. R. and O'Rear, J.G.: The synthesis of fluorinated acrylics via fluoro tertiary alcohols, Biomedical and dental applications of polymers, Polymer Science and Technology (14), Prenum Press, New York, 1979, pp. 373-377.

14) Douglas., W. H., Craig, R. G. and Chen, C. J. : A new composite restorative based on a hydrophobic matrix, J Dent Res 58 (10) : 1981-1986, 1979. 


\section{細胞培養法による $\mathrm{Ni}-\mathrm{Cr}$ 合金の細胞毒性の評価 兼松宣武*，土屋博紀**，佐藤 勝***，山本宏治****，浅井昭士郎*** 高木順彦**，並河 勇***，柴田寛一*，藤井輝久 \\ *朝日大学歯学部口腔外科学第 2 講座 \\ **朝日大学歯学部歯科薬理学講座 \\ ***朝日大学歯学部口腔細菌学講座 朝日大学歯学部歯科保存学第 1 講座 \\ *****朝日大学歯学部歯科補綴学第 3 講座}

数種の市販 $\mathrm{Ni}-\mathrm{Cr}$ 合金の細胞毒性をマウス線維芽細 胞（L 929）を用いた培養法により検討した。細胞を合金 試料と共に培養した後の細胞生存率とコロニー形成率を 対照（ガラス）と比較することにより毒性を検定した。 本実験で供試した合金は細胞の生存性とコロニー形成に 刘して一様に毒性を示したが，その程度は合金の種類に よって異なっていた。標準の $\mathrm{Ni}-\mathrm{Cr}$ 二元合金において は, その細胞毒性は合金からの $\mathrm{Ni}$ の溶出量と密接に相
関することが示された。細胞毒性, $\mathrm{Ni}$ の溶出量は共に合 金中の Cr 含量に依存しており，Cr 含量が 15\%以下にな ると急激な細胞毒性の上昇が認められた。しかし市販の $\mathrm{Ni}-\mathrm{Cr}$ 合金の場合，その細胞毒性の強さを $\mathrm{Ni}$ の溶出性 と Cr の相対的な含量との関係のみに基づいて説明する ことはできなかった。この結果は $\mathrm{Co}, \mathrm{Cu}$ といった合金 中の他の成分の影響あるいは, Cr 含有量に依存した合金 組織内の不均一性によるものと推察された。

\section{アクリル系義歯床用レジンの衝撃特性}

\section{一第 1 報一衝撃特性を決定する方法}

\section{奥 淳一}

鹿児島大学歯学部歯科理工学講座

硬質プラスチックの耐衝撃性は,シャルピーあるいは アイゾット衝撃試験機を使用して検討されているが，こ れらの試験機は高速 $(3.35 \mathrm{~m} / \mathrm{s})$ で単一スピードである こと，また歯科修復物のような比較的小さい試験片では, 衝撃破壊に関する情報を得にくいなどの欠点がある。こ の問題を解決するために，小試験片で測定が行なえる衝 撃試験機を考案し, PMMAレジンの衝撃特性を調べた。 衝撃強さ,レジリエンスおよび靱性は，試験片のスパ ンが小さいものほど大きく，ノッチ部を除く有効断面積
が大きいものほど大きな值を示した。衝撃スピードが $13.5 \mathrm{~cm} / \mathrm{s}$ (平均咬合スピード) から $50.0 \mathrm{~cm} / \mathrm{s}$ までの範 囲内では，スパン $3.0 \mathrm{~cm}$ とした場合の衝撃強さは一定 の值 $\left(1.16 \times 10^{3} \mathrm{~J} / \mathrm{cm}^{2}\right)$ を示したが，それ以上のスピー ドでは減少した。常温重合レジンでは, 重合後の時間経 過にともなう物性変化に関する情報も得られた。時間の 経過につれて破壊係数はしだいに大きくなり, 衝撃強さ は減少した。重合後 1 週間では,これらの值は加熱重合 レジンや熱処理試料の值に近づいた。

\section{可視光線重合型 unfilled resin の物性に及ぼすモノマー構造の影響}

\section{川口 稔, 福島忠男, 堀部 隆} 福岡歯科大学歯科理工学教室

分子内にビスフェノール骨格を有する 9 種のジメタク リレート (Bis-GMA, Bis-GMA-F, Bis-GMA-C, BisGMA-EPh, Bis-GMA-ECh, Bis-MEPP, Bis-MEEPP,
Bis-MPPP, Bis- $\left.\mathrm{ME}_{2.6} \mathrm{PP}\right)$ と triEDMA より成る光重合 型の unfilled resin を試作し, 重合体の機械的性質と吸水 性を測定することにより，モノマーの分子構造と重合体 
の物性との関係を検討した。ビスフェノールAやフルオ ロビスフェノールA骨格を有するジメタクリレートの重 合体は, 総体的に良好な機械的性質を示し, 各重合体の 物性が，モノマーの分子構造の剛直性および柾水性に よって影響を受けることが明らかとなった。また，運動
性に乏しい分子構造のモノマーでは, 立体障害によるも のと考えられる物性の低下が認められた。フルオロ基を 有するビスフェノール骨格のジメタクリレートは比較的 優れた物性ならびに耐水性を示し, 修復用レジンのベー スモノマーとしての有用性が示唆された。

\title{
人歯牙象牙質のねじりにおける動的ずり弾性率
}

\author{
有川裕之，井上勝一郎
}

鹿児島大学歯学部歯科理工学講座

人柬牙の種々の物性についての報告は比較的少なく， 末解明の部分が多い。なかでも歯牙の粘弾性的性質は口 腔内における修復材料の挙動に大きく影響するものとみ られることから重要である。本研究ではねじれ自由減衰 型粘弾性測定装置をもちいて人歯牙象牙質の動的ずり弾 性率の測定を試みた。

試料は履歴の判明した新鮮抜去茵をマイクロカッター にて短冊状に切断し測定に供した。測定は雾囲気温度を $1^{\circ} \mathrm{C} / \mathrm{min}$ の速度で昇温し, $23^{\circ} \mathrm{C}$ から $150^{\circ} \mathrm{C}$ の温度範囲に
わたっておこなった。

弾性率 $(\mathrm{G})$ は温度の上昇に伴ってわずかに大きくなる 傾向がみられたが, 温度による弾性率の変化は小さかっ た。損失率 $(\tan \delta)$ は $75^{\circ} \mathrm{C}$ 付近にピークがみられた。 $37^{\circ} \mathrm{C}$ における 20 個の試料の弾性率の值は小さいもので $5.77 \times 10^{10} \mathrm{dyne} / \mathrm{cm}^{2}$, 大きいもので $1.06 \times 10^{11} \mathrm{dyne} /$ $\mathrm{cm}^{2}$ であった。各試料の弾性率と試料を作成した歯牙の 履歴との間に明確な相関はみられなかった。

\section{MKG による鈎歯の挙動の分析}

\section{第 1 報, $M K G$ 記録の特性ならびにその修正} 守川雅雄*, 迫 雅裕 ${ }^{*}$, 城戸寛史 ${ }^{*}$, 豊田静夫*, 小園凱夫**

*九州歯科大学歯科第一補綴学講座

補綴物を製作する上で最も重大な関心事は, その補綴 物に最適なデザインを決定することであろう。とくに パーシャル・デンチャーにおいては,このことは不可久 な問題である。この問題を解決するために従来から,パー シャル・デンチャーの鈎歯の機械的な挙動を分析するこ とによって判定しようとする試みがストレイン・ゲージ 法, 光弾性法, 有限要素法, その他の方法を用いてなさ れ数多くの報告がある。しかし，いずれも三次元的な観
**九州歯科大学雬科理工学講座

察が困難であったり，物性值に問題があるなどの難点が ある。

著者らは, 鈎歯の三次元的な挙動を分析するために $\mathrm{MKG}$ を応用することを試み, 今回, その MKG の特性に ついて検討した。その結果, MKGのディスプレー上に表 示される運動記録にはかなりのひずみが生じるが，近似 的な補正が可能であり，鈎歯の挙動の定性的な観察には 有効な方法であることが判明した。 